\title{
VELEBIT I ZAŠTITA PRIRODE
}

Zoran Šikić

Denis Gurlica

Tomislav Šarić

Sveučilište u Zadru

Odjel za ekologiju, agronomiju i akvakulturu

Trg kneza Višeslava 9

HR 23000 Zadar

zoran.sikic@gmail.com

dgurlica@gmail.com

tosaric@unizd.hr
UDK: 502.7(497.5)(234 Velebit)

Pregledni članak

Ur.: 2016-10-22

Velebit je kultna i mitska hrvatska planina, "sveta gora", simbol nacionalnog identiteta. On je i perjanica hrvatskih zaštićenih područja prirode, UNESCO-ov (Organizacija Ujedinjenih naroda za obrazovanje, znanost i kulturu) rezervat biosfere od 1978., Park prirode od 1981., a dio pripada nacionalnom parku Paklenica od 1949. i nacionalnom parku Sjeverni Velebit od 1999. U cijelosti je dio ekološke mreže EU Natura 2000, što jasno upućuje na širi globalni značaj. Za dobra vremena cijeli se Velebit vidi iz zraka s visine od $8.000 \mathrm{~m}$ te ima oblik bedema koji se u luku izbočio u more. Viša je primorska padina koja se od mora pruža u visini od $700 \mathrm{~m}$ do najnižeg prijevoja, pa do $1.757 \mathrm{~m}$ najvišeg vrha. Sa sjeverne kopnene strane padina se od $150 \mathrm{~m}$ do $1.150 \mathrm{~m}$ uzdiže iznad ličke visoravni koja leži na 500 do $600 \mathrm{~m}$ nadmorske visine. Velebit je centar bioraznolikosti te najznačajnije endemsko čvorište flore i kopnene faune u Republici Hrvatskoj. Prema posljednjem izdanju Liste zaštićenih područja Ujedinjenih Naroda - UN - iz 2003. u svijetu je zaštićeno 102.102 područja s ukupno zaštitom od 11,5\% kopnene i $0,5 \%$ morske površine Zemlje. U RH prema Upisniku zaštićenih područja Ministarstva zaštite okoliša i prirode sa stanjem od 9. rujna 2015.,ukupno je zaštićeno 408 područja koja obuhvaćaju 8,56\% ukupne površine RH, odnosno 12,23\% kopnenog teritorija i 1,94\% teritorijalnog mora što je iznad svjetskog prosjeka. Najveći dio zaštićenih površina je u kategoriji parkova prirode na koje otpada 4,56\% ukupne površine RH, a najveći doprinos tome daje upravo Velebit. Važeći Zakon o zaštiti prirode utvrđuje devet kategorija zaštićenih područja, a koje u najvećoj mjeri odgovaraju jednoj od međunarodno priznatih kategorija zaštićenih područja IUCN - Međunarodne unije za zaštitu prirode. Šire područje Paklenice s površinom od 9.500 ha je zbog svoje prirodne osnove, geomorfoloških oblika i očuvanih šuma proglašeno među prvima nacionalnim parkom (iste godine kad i Plitvička jezera). U sjevernom dijelu Velebita 1999. s površinom od 10.900 ha proglašen je nacionalni park Sjeverni Velebit, prepoznatljiv po bioraznolikosti i iskonskoj divljini. U viziji 
nacionalnog parka Sjeverni Velebit upravo to je istaknuto kao oslonac održivog razvoja lokalne zajednice temeljen na tradiciji, ali i kao prostor stjecanja novih spoznaja. Osim dva nacionalna parka preostali dio Velebita u površini od 200.000 ha zaštićen je u kategoriji parka prirode. Sve navedeno upućuje na iznimno visok doprinos Velebita zaštiti prirode. Da li je i na koji način zaštita prirode doprinos opstanku i održivom razvoju velebitske regije i posebno lokalne zajednice tog područja još uvijek je aktualno pitanje te također, je li na ovome prostoru moguće povezati opće i globalne izazove današnjice s onim lokalnim.

Ključne riječi: Velebit, zaštićena područja, bioraznolikost, održivi razvoj

\section{Uvod}

Vrlo važno je okupiti znanstvenike i eksperte iz različitih znanstvenih područja kako bi se interdisciplinarno povezali rezultati koji se odnose na Velebit, a posebno Podgorje. Zapaženo je nekoliko primjera izrade monografija i studija o pojedinim podgorskim naseljima kao i primjeri muzejskog čuvanja kulturne baštine, što jasno ukazuju na prisutnost želja i potreba koje streme drugačijim odnosima spram aktualne stvarnosti i razvojnih mogućnosti. Poznavatelji prilika polaze od teze da pokretanje uspješnijeg razvitka u Podgorju nije ni lagan ni jednostavan proces. U tom pogledu sve intencije i napori lokalnih vlasti, ustanova, udruga i pojedinaca zaslužuju širu znanstvenu, stručnu i inu potporu.

$\mathrm{Na}$ znanstveno-stručnom skupu "Podgorje: polazišta i perspektive razvoja kraja između Velebita i Jadrana", obrađen je prostor između Svetog Jurja i Starigrada-Paklenice, i to: prostorni opseg, ime, geopolitički položaj, zemljopisna obilježja, stanovništvo, mreža naselja, demografska kretanja, podgorsko iseljeništvo, povijesna zbivanja i procesi od starih vremena do kraja Domovinskog rata, gospodarske i socijalne djelatnosti u prošlosti i sadašnjosti, razvitak i evaluacija prometne mreže, pomorskog prometa i tehničke infrastrukture, uloga Katoličke crkve u razvitku Podgorja, tradicijska kultura, graditeljska baština, narodni život i običaji, razvitak školstva, jezik i književnost, nacionalni i socijalni identitet Podgoraca. Međutim, ocjena prirodnih potencijala, održivog razvoja i zaštite okoliša, dosadašnji oblici i dosezi planiranja, naročito su bitni za potencijale i perspektivu razvoja. Ovaj rad upravo se na pregledan način bavi prvo navedenim, prirodnim potencijalima toga prostora.

Velebit je ukupno najveća hrvatska, i najduža planina Dinarskog krša. Pruža se smjerom sjeverozapad - jugoistok i zahvaća tri hrvatske regije: Liku, Dalmaciju i Hrvatsko primorje. Prirodne međe su mu Velebitski kanal Jadranskog mora, a s druge strane ličko-gacka visoravan. Na jugu je omeđen rijekom Zrmanjom, a na sjeveru ga prijevoj Vratnik dijeli od ogranka Kapele. Od Vratnika do Zrmanje Velebit se povija u blagom luku dužine oko 145 kilometara, dok je zračna linija na 
tom potezu duga 132 kilometra. Možemo ga podijeliti na četiri područja: Sjeverni Velebit započinje s prijevojem Vratnik, a završava na prijevoju iznad primorskog naselja Jablanac (dužine je oko $30 \mathrm{~km}$, a isto toliko najveće širine); Srednji Velebit završava na prijevoju Baške Oštarije preko kojeg vodi cesta Karlobag - Gospić (dužina tog dijela je oko $24 \mathrm{~km}$, a najveće širina do $20 \mathrm{~km}$ ); Južni Velebit završava na prijevoju Mali Alan, na staroj cesti koja spaja Obrovac i Lovinac (dužine je oko $46 \mathrm{~km}$, a najmanje širine oko $10 \mathrm{~km}$ ) te Jugoistočni Velebit započinje na istom prijevoju, a završava uz kanjon rijeke Zrmanje i dužine je oko $40 \mathrm{~km} .{ }^{1}$

U starom i srednjem vijeku velebitski prostor je bio naseljen, a stanovništvo se bavilo stočarstvom i ratarstvom te su upravo stočarstvo, ratarstvo i drvo bili predmet trgovačke razmjene, koja se tada odvijala preko Senja, Karlobaga, Starigrada, Obrovca i Zadra. Međutim, s vremenom su mlađe generacije potpuno promijenile patrijarhalni način života na Velebitu. Želja za lakšim načinom života i višim životnim standardom je primamila mlađe naraštaje u gradove odnosno da napuštaju svoja ognjišta. Planinski dijelovi Velebita su postajali sve napušteniji sa sve više napuštenih kuća i porušenih suhozida. ${ }^{2} \mathrm{~S}$ druge strane tzv. odgovori društva, nisu osigurali mehanizme zaustavljanja takvih negativnih depopulacijskih procesa. U takvoj situaciji, puno puta upravo je zaštita prirode velebitskog područja percipirana kao glavni razlog takvih negativnih trendova.

Sve do 60-ih godina 20. stoljeća smatralo se kako su sva prirodna, živa i neživa dobra tu samo da služe čovjeku, a prirodna dobra da su neiscrpna. Taj pogled, tj. sustav, nazvan je antropocentričan sustav (čovjek u sredini) i vladao je čovječanstvom sve dok se nisu počele primjećivati štetne posljedice takva pristupa. Danas se sve više, u razvojnoj viziji svijeta, naglašava ekocentrični sustav, čije je polazište ekosustav, ukupnost živih i neživih organizama na Zemlji, koji između sebe izmjenjuju materiju, energiju i informacije. Po Zakonu o zaštiti prirode (NN 80/13) priroda je sveukupna bioraznolikost, krajobrazna raznolikost i georaznolikost, a zaštita prirode se provodi očuvanjem navedenih elemenata.

Održivi razvoj u svojoj biti pretpostavlja usklađivanje ekonomskih, ekoloških i društvenih aspekata razvoja te je stoga presudna interdisciplinarnost pristupa. S druge strane pak, ukoliko želimo promatrati sektorski odvojeno, možemo zaključiti kako je ekonomiste uvijek zanimao ekonomski rast i učinkovitost, ekologe zaštita i cjelovitost ekosustava, a sociologe pravednost i sigurnost za sve članove društva. ${ }^{3}$

\footnotetext{
${ }^{1}$ A. PELIVAN, 2007, 21-63.

${ }^{2} \mathrm{http}: / /$ velebit.meridian-arts.com

${ }^{3}$ Z. ŠIKIĆ, 2015.
} 
Svrha ovoga rada je analiza stanja zaštite prirode velebitskog prostora, odnosno dobiti načelan odgovor na pitanje je li zaštita prirode doprinos održivom razvoju velebitske regije i posebno lokalne zajednice te je li na ovom prostoru moguće povezati opće i globalne izazove današnjice s onim lokalnim.

\section{Razrada}

Položaj

Velebit je hrvatska planina, simbol nacionalnog identiteta koji pripada planinskom lancu Dinarida. Velebit je približne površine $2270 \mathrm{~km}^{2}$ i na toj površini ima više od 130 vrhova koji prelaze nadmorsku visinu od 1370 metara. Najviši vrh je Vaganski vrh (1757 m) koji se nalazi u južnom i ujedno najvišem dijelu Velebita. Svojim najvećim dijelom Velebit se prostire uz more i pruža u visinu od 700 metara do najnižeg prijevoja pa do najvišeg vrha od $1757 \mathrm{~m} .{ }^{4}$ Ako se Velebit promatra unutar hrvatskog geografskog prostora, razvidno je da taj planinski masiv spaja na sjeverozapadu Gorski kotar sa sjevernom Dalmacijom na jugoistoku. S druge strane može se reći da razdvaja Liku od obale Jadranskog mora. ${ }^{5}$

\section{Reljef}

Uzme li se u obzir reljefni i geomorfološki pogled jasno se razlikuju primorska i lička strana Velebita. S primorske strane Velebita nalazi se nekoliko različitih cjelina. Naime, neposredno uz more na primorskoj strani uzduž Velebita nalazi se terasa ili stuba uz koju su stanovnici gradili svoja naselja. Na većim visinama, od 800 do 1000 metara prostire se druga stuba ili terasa u okviru koje nalazimo brojna krška polja, doline, dolce i kukove, koji tom dijelu Velebita daju izuzetan reljefni izgled. Pojedini dijelovi primorske strane Velebita privlače pozornost dobro razvijenim i očuvanim šumama koje daju pitomiji izgled primorskim obroncima. Lička ili kontinentalna strana naše najveće i najljepše planine po svojim reljefnim osobitostima značajno se razlikuje od primorske strane. Na kontinentalnoj strani se ne pojavljuju uzdužne terase ili stube koje su odlika primorske strane Velebita, nego su to uglavnom blagi obronci koji se spuštaju u Gacko i Ličko polje. Valja istaknuti da se ni svi dijelovi kontinentalne strane ne odlikuju istim reljefom. Promatrajući Velebit s ličke strane na njegovu sjevernom i srednjem dijelu mogu se uočiti gorske kose između kojih se prostiru

${ }^{4}$ S. FORENBAHER, 2001, 2-22.

${ }^{5}$ A. PELIVAN, 2007, 21-63. 
doline ili dulibe, kao što su Krasanska duliba, Apatišanska duliba, Lomska duliba i druge. Južni dio Velebita s ličke strane ima drugačiji reljef zbog uzdužnog rasjeda koji se prostire pod najvišim velebitskim vrhovima. Iznad rasjeda se nalaze točila, a ispod njih obronci obrasli gustom šumom sa završetkom u Ličkom polju. ${ }^{6}$ Velebit u svojoj unutrašnjosti ima sasvim drugačiju reljefnu sliku od svojih bočnih strana. Bogatstvo geomorfoloških oblika i različitost reljefnih oblika, kao što su udoline, korita, dulibe, škrape i ponikve, neće ostaviti ravnodušnim nijednog posjetitelja Velebita. Na svom jugoistočnom dijelu, na kojem su najviši velebitski vrhovi Vaganski vrh $(1757 \mathrm{~m})$ i Sveto brdo (1751 m) dva niza vrhova se sastaju u jedan pri čemu čine planinsko bilo. Bitno reljefno obilježje Velebita su kukovi nevjerojatnih oblika koji nastaju nejednakim kemijskim i mehaničkim trošenjem stijena i litica. Bogatstvu velebitskog masiva svakako treba pridodati špilje i ponore kao dio podzemnog dijela planine. Uz mnogobrojne do sada otkrivene jame i špilje može se očekivati da ima još speleoloških objekata. ${ }^{7}$

\section{Klima}

Klimatske prilike na Velebitu odraz su njegova zemljopisnog položaja i smjera pružanja, a sam reljef određuje mikroklimatske prilike na njegovu području. Općenito se za podneblje Velebita može reći da je vrlo oštro. Duljina trajanja hladnog razdoblja u gorskim i pretplaninskim predjelima je znatno duža (traje od listopada do polovice svibnja) u usporedbi s toplijim razdobljem koje traje kraće (od lipnja do kraja rujna). Što se tiče razlika srednjih temperatura u hladnom i toplom razdoblju valja reći da one na visinama od $1500 \mathrm{~m}$ i više i nisu izrazito velike; razlika srednje dnevne temperature izmjerene na Zavižanu u siječnju i kolovozu iznosi $17^{\circ} \mathrm{C}$. Međutim, velike su oscilacije u temperaturama između pojedinih mjeseci i dana, i između dana i noći. ${ }^{8}$ Jedan od glavnih klimatskih čimbenika na velebitskom masivu je količina oborina, koja ima utjecaj na prirodna obilježja te na rasprostranjenost biljnog i životinjskog svijeta. Razvidno je naime da porastom visine raste i količina oborina. Najmanje količine oborina padnu uz obalu u podnožju velebitskog masiva ovisno o nadmorskoj visini i penju se prema višim vrhovima (tako npr. na Svetom brdu dosegnu preko $3.000 \mathrm{~mm}$ godišnje). Znakovit je porast oborina od sjeverozapada prema jugoistoku, od Senjskog bila, gdje je količina oborina oko $1.500 \mathrm{~mm}$ godišnje

\footnotetext{
${ }^{6}$ A. PELIVAN, 2007, 21-63.

${ }^{7}$ A. PELIVAN, 2007, 21-63.

${ }^{8}$ S. FORENBAHER, 2001, 2-22.
} 
do Malog Alana gdje iznosi oko $4.200 \mathrm{~mm}$ godišnje. ${ }^{9}$ Oborine su raspoređene tako da je najveći dio u zimskim i proljetnim mjesecima, a najmanji tijekom ljetnog razdoblja. ${ }^{10}$ Kao jedno od važnih klimatskih obilježja na velebitskom masivu zasigurno se može ubrojiti i snijeg. Snijeg je rijetka pojava na primorskoj strani Velebita, a ako ga i bude zadržava se samo kraće vrijeme, dok na ličkoj strani i osobito na velebitskim vrhovima snijega ima dosta i zadrži se prilično dugo. ${ }^{11}$ Snijeg se na Velebitu na sjevernim i sjeveroistočnim padinama zadrži čak do kraja svibnja, a u tzv. jamama sniježnicama može ga se naći i cijelu godinu. ${ }^{12}$ Specifičnosti velebitske klime pridonose zasigurno vjetrovi, od kojih se posebno ističe bura. Bura kao izrazito suh i hladan vjetar puše na mahove $i$ često za vrijeme zimskih mjeseci otežava promet podvelebitskim prometnicama ili pak plovidbu u podvelebitskom kanalu. ${ }^{13}$ Bura je vjetar koji smanjuje relativnu vlažnost zraka, pospješujući isparavanje pridonosi isušenju tla. Nepovoljan utjecaj bure se očituje na šumskom i drugom raslinju, jer osim što isušuje zrak i tlo, odnosi i čestice tla pa biljke ostaju ogoljenog korijena i trpe znatne štete. Time bura jasno očituje svoj erozivni karakter, a drveće i drugo raslinje koje se nalazi izloženo buri izobličeno je i zakržljalo. ${ }^{14}$ Međutim, osim negativnog utjecaja bure, pitanje da li bi se mogla imati i korist od nje još je uvijek predmet polemika. Svojim geografskim položajem velebitski masiv dijeli dvije klimatske regije: kontinentalnu i mediteransku. Sama ta podjela i nije tako oštra što se najbolje očituje na flori i vegetaciji u različitim klimatskim prijelazima.

\section{Biljni i životinjski svijet Velebita}

Za Velebit se može reći da je centar bioraznolikosti te najznačajnije endemsko područje flore i kopnene faune u $\mathrm{RH} .{ }^{15}$ Biljnom bogatstvu Velebita i pojavi velikog broja endema uvelike je pridonio njegov geografski položaj. ${ }^{16}$ Naime, ispreplitanje srednjoeuropskog i sredozemnog vegetacijskog područja koji su u svojoj osnovi bitno različiti znatno su doprinijeli različitosti biljnog svijeta Velebita. Velebit je specifičan po tome što su uz uvjete za naseljavanje

\footnotetext{
${ }^{9}$ A. PELIVAN, 2007, 21-63.

${ }^{10} \mathrm{~S}$. FORENBAHER, 2001, 2-22.

${ }^{11}$ A. PELIVAN, 2007, 21-63.

${ }^{12}$ S. FORENBAHER, 2001, 2-22.

${ }^{13}$ A. PELIVAN, 2007, 21-63.

${ }^{14} \mathrm{~S}$. FORENBAHER, 2001, 2-22.

${ }^{15}$ Državna uprava za zaštitu prirode i okoliša, Zagreb, 1999.

${ }^{16}$ A. PELIVAN, 2007, 21-63.
} 
novijih biljnih vrsta istovremeno zadržani povoljni uvjeti za opstanak biljaka starosjedilaca. Upravo činjenica da su biljke starosjedioci nalazile utočište u izdvojenim mikro ambijentima i time preživjele doba oledbi rezultirala je velikim brojem endema reliktnog ili progresivnog karaktera. Smatra se da je Velebit postojbina 79 biljnih endemskih vrsta. Od velebitskih endema ističe se veoma rijetka velebitska degenija (Degeniavelebitica), zatim su tu hrvatska gušarka (Cardaminopsiscroatica), prozorski zvončić (Campanulafenestrellata), hrvatsko zvonce (Edraianthusgraminifolius var. croaticus). Također su tu endemske vrste karakteristične za Hrvatsku kao što su hrvatska sibireja (Sibiraeaaltaiensisssp.croatica) sitno ili Malijevodevesilje (Seselimalyi), Valdštajnova zvončika (Campanulawaldsteiniana) i dr. Ipak, Velebitom dominiraju endemi koji pripadaju dinarskom planinskom sustavu kao što su nježna pljeskarica (Arenariagracilis), velecvjetnirožac (Cerastiumgrandiflorum), Kitaibelov jaglac (Primulakitaibeliana) i mnogi drugi. ${ }^{17}$ Velebitskim masivom uglavnom dominiraju tri vegetacijska tipa: vegetacije šuma, travnjačka i livadna vegetacija, zatim vegetacija koja se razvila na stijenama i točilima. Zajednice šuma svakako su najrazvijenije i najzastupljenije biljne zajednice na Velebitu. $\mathrm{Na}$ primorskoj strani dominira šuma hrasta medunca (Quercuspubescens) i bijelograba (Carpinusorientalis) koje se nalaze do otprilike 400 metara visine od obale. Manje površine na primorskoj strani zauzimaju šume ilirskog crnog bora (Pinetumnigraesubmediteraneum). Kao autohtone velebitske biljne vrste, crni bor (Pinus nigra) uz crni grab (Ostrya carpinifolia) dominantne su vrste te zajednice. Zajednice primorske bukove šume (Seslerio fagetum) nadovezuju se na šume hrasta medunca i crnog graba. Bukva (Fagussylvatica) koja osim što se nalazi i na primorskoj strani velebitskog masiva i na ličkoj strani zauzima velike površine. Značajno je napomenuti da zajednice bukovih šuma također dominiraju na najvišem velebitskom pojasu. Osim bukovih šuma značajne su zajednice šume jele (Abiesalba) i zajednice smrekovih šuma (Picetumillyricummontanum) uz smreku (Piceaabies) kao glavnu vrstu. Na najvišim velebitskim vrhovima dominira tip vegetacije u kojem je bor krivulj (Pinusmugo)dominatna vrsta. Ta zajednica se uspješno prilagodila na surove uvjete klime koji prevladavaju na velebitskim vrhovima. Velike površine u primorskom pojasu, koje su nekad bile stanište autohtonih šumskih zajednica, ljudskom djelatnošću i djelovanjem domaćih životinja pretrpjele su značajne promjene, naime. pretvorene su u travnjake i livade na kojima je razvijen poseban tip vegetacije. Dakako, uz šumske zajednice i zajednice travnjaka i livada, na Velebitu možemo naći zajednice točila

${ }^{17}$ S. FORENBAHER, 2001, 2-22. 
i stijena na kojima se razvio nevjerojatno bogat svijet velebitskih endema. ${ }^{18}$ Glavne krajobrazne značajke najviših predjela su ogoljele krške formacije koje se izmjenjuju sa šumskim dolinama i suhim travnjačkim površinama.

U usporedbi s velebitskim biljnim svijetom može se reći da je još uvijek nedovoljna istraženost životinjskog svijeta rezultirala manjim spoznajama o tom vrlo živopisnom i bogatom svijetu s popriličnim brojem endemskih vrsta. Velebit sa svojim specifičnim položajem i klimom, kao i različitim vrstama staništa, pridonosi bogatstvu životinjskog svijeta, posebice ptica i leptira. Određeni utjecaj na ptičji svijet čini sječa šuma i dolazak brojnih posjetitelja. ${ }^{19}$ Ugroženost se posebno reflektira na ptice grabljivice kao što su sivi sokol (Falcoperegrinus), suri orao (Aquilachrysaetos) i druge. Prema postojećim podatcima na području Velebita do danas je zabilježeno:10 vrsta vodozemaca, 26 vrsta gmazova, 23 vrste sitnih sisavaca (kukcojeda i glodavaca), 23 vrste šišmiša. Velebit je područje rasprostranjenja svih triju velikih zvijeri - mrkog medvjeda (Ursusarctos), vuka (Canislupus) i risa (Lynxlynx), kao i obitavalište vidre (Lutralutra). Velebit kao dinarsko krško područje je od iznimne važnosti za vrste podzemnih staništa među kojima nalazimo 23 svojte endemične za Hrvatsku, a dio njih za Velebit. U okviru izrade prijedloga mreže Natura 2000, Ornitološki zavod HAZU - Hrvatske akademije znanosti i umjetnosti je Velebit izdvojio kao ornitološko područje gdje populacije 18 vrsta ptica zadovoljavaju klasifikacijske kriterije za europsku mrežu Natura 2000. Na Velebitu se nalaze najvažnije gnjezdilište vrtne strnadice (Emberizahortulana) (1500-2500 parova), jedno od najvažnijih gnjezdilišta tetrijeba gluhana (Tetraourogallus) u Hrvatskoj, malog ćuka (Glaucidiumpasserinum), planinskog ćuka (Aegoliusfunereus) te planinskog djetlića (Dendrocopuspusleucotos) ${ }^{20}$ Danji leptiri su izuzetno zanimljiva životinjska skupina, a samo na području Nacionalnog parka Paklenica (u daljnjem tekstu NP Paklenica) ima 80 različitih vrsta, što predstavlja preko $40 \%$ faune danjih leptira u Hrvatskoj. ${ }^{21}$

Zaštita prirode Velebita

Velebit je sa svojom površinom od preko 200.000 ha 1981. godine proglašen parkom prirode i time predstavlja najveće zaštićeno područje u

\footnotetext{
${ }^{18}$ A. PELIVAN, 2007, 21-63.

${ }^{19}$ D. GURLICA, 2016,

${ }^{20} \mathrm{http} / / /$ www.ppvelebit.hr

${ }^{21}$ J. ROTA, 1999, 26-27.
} 
Hrvatskoj koje čini gotovo $27 \%$ ukupno zaštićenih površina u RH. ${ }^{22}$ Naime, uz cijeli Velebit kao kategoriju parka prirode na njegovu području se nalaze i dva nacionalna parka, Paklenica (Sl. 1) i Sjeverni Velebit ${ }^{23}$. Nacionalni park Paklenica je zbog svojih prirodnih osobitosti, geomorfoloških oblika, bogatog biljnog i životinjskog svijeta te napose očuvanih šuma među prvima (1949. godine) proglašen nacionalnim parkom ${ }^{24}$. U sjevernom dijelu Velebita 1999. godine proglašen je Nacionalni park Sjeverni Velebit (u daljnjem tekstu NP Sjeverni Velebit) koji se ističe bioraznolikošću i iskonskom divljinom. Naime, na tom relativno malom prostoru golemo je bogatstvo živog svijeta i osebujnih krških oblika unutar kojeg se ističe Strogi rezervat Hajdučki i Rožanski kukovi. NP Sjeverni Velebit uz svoje osobitosti u budućnosti može biti oslonac održivog razvoja lokalne zajednice koji se temelji na tradiciji, ali i kao prostor koji nudi nove spoznaje ${ }^{25}$. UNESCO je pokrenuo Program 'Čovjek i biosfera' (MAB - Man and the Biosphere Programme) još 1970. godine, kao međuvladin znanstveni program koji ističe važnost uspostave ravnoteže između očuvanja bioraznolikosti $\mathrm{s}$ jedne strane i razvojnih potreba lokalne zajednice s druge strane. U sklopu ovog Programa, 1974. godine je počela uspostava svjetske mreže područja koja predstavljaju glavne ekološke sustave na Zemlji, unutar kojih se štiti genetska raznolikost kao preduvjet biološke raznolikosti, te gdje se provode istraživanja ekoloških sustava, praćenje njihova stanja i edukacija ${ }^{26}$. Pojedina područja ove mreže nazivamo rezervatima biosfere, kao međunarodno priznatim područjima unutar UNESCO-ovog MAB Programa koji promoviraju rješenja za skladan odnos između zaštite biološke raznolikosti i njezina održivog korištenja, kroz ispunjavanje tri osnovne funkcije rezervata biosfere:

- zaštitnu funkciju - doprinose očuvanju krajobraza, ekoloških sustava, vrsta i genetske varijabilnosti;

- razvojnu funkciju - potiču ekonomski i društveni razvoj koji je sociokulturno i ekološki održiv;

- logističku funkciju - osiguravaju podršku istraživanju, praćenju stanja, edukaciji i razmjeni informacija o zaštiti i održivom razvoju na lokalnoj, nacionalnoj i globalnoj razini.

\footnotetext{
${ }^{22}$ I. MARTINIĆ, 2010,

${ }^{23}$ J. ANTOLOVIĆ - M. PLESKALT - Z. ŠIKIĆ, 2010, 41-43.

${ }^{24}$ NP Paklenica, 2007, 6-47.

${ }^{25}$ NP Sjeverni Velebit, 2007, 6-51

${ }^{26}$ J. ANTOLOVIĆ - M. PLESKALT - Z. ŠIKIĆ, 2010, 17.
} 


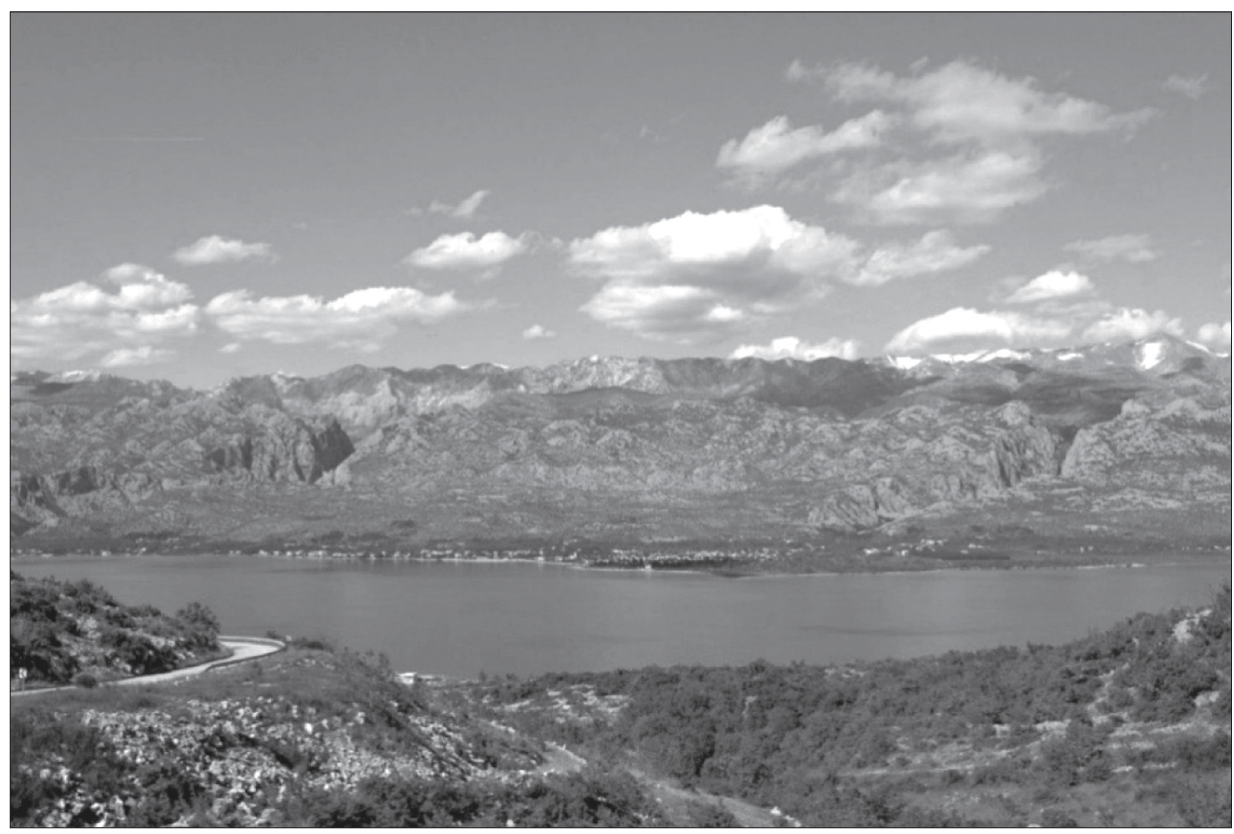

S1. 1. Pogled na NP Paklenica i masiv Velebita, foto: D. Gurlica

Planina Velebit je naš prvi rezervat biosfere proglašen 1978. godine netom nakon uspostave svjetske mreže rezervata biosfere.

Ulaskom Hrvatske u EU, Velebit je postao dio ekološke mreže Natura 2000, što, jasno, očituje širi globalni značaj ove planine. Bez obzira što je europska priroda zbog ljudskih djelatnosti znatno izmijenjena, ipak se može reći da još uvijek pokazuje veliku raznolikost staništa. Zadnjih desetljeća ljudska djelatnost uvelike je promijenila bioraznolikost i prirodne resurse. Svjedoci smo izumiranja i ugroženosti vrsta veoma jakog intenziteta, pa je samo u Europi u Crveni popis vrsta kojima prijeti izumiranje upisano više od 700 vrsta, većinom ptica i sisavaca. Ugrozu trpe ne samo rijetke vrste i endemične svojte nego i mnoge vrste koje još uvijek pokazuju veliku brojnost, ali im zbog ubrzanog nestajanja njihovih staništa prijeti opasnost od izumiranja. Zbog zaustavljanja ovih negativnih trendova opadanja bioraznolikosti i prijetnje izumiranja vrsta EU - Europska unija je na svojem teritoriju utemeljila program Natura 2000. ${ }^{27}$ Natura 2000 predstavlja ekološku mrežu EU koja se sastoji od područja važnih za očuvanje ugroženih vrsta i stanišnih tipova u EU. Glavni cilj ekološke mreže

${ }^{27}$ www.dzzp.hr 
Natura 2000 je očuvanje ili ponovno uspostavljanje povoljnog stanja za više od tisuću ugroženih i rijetkih vrsta, kao i za očuvanje oko 230 prirodnih i poluprirodnih staništa. Natura 2000 je najveća ekološka mreža očuvanih područja u svijetu jer je u nju uključeno oko 30.000 područja što čini blizu $20 \%$ teritorija $\mathrm{EU}^{28}$. Postoje dva aspekta gledišta na Naturu 2000: s jedne strane smatra se jednim od najvećih uspjeha zaštite prirode u Europi, dok oponenti tvrde da Natura 2000 ne ispunjava svoju svrhu te da biološka raznolikost i dalje opada. Natura 2000 je do svog utemeljenja prošla dug put, a kao temelj njezina početka je 1979. godina kada je prihvaćena Direktiva o pticama. Naime, tada su zemlje članice Europske zajednice prepoznale narušenost prirodne ravnoteže koja se očitovala u smanjenju broja divljih ptica. Tom prilikom su predložene mjere koje bi ublažile posljedicu ljudske aktivnosti, tako da se spriječi uništavanje i onečišćenje staništa ptica, a na poseban način sprječavanje hvatanja i ubijanja te nedopuštene trgovine divljim pticama. Kako gubitak staništa predstavlja najveću prijetnju pticama Europe, Direktivom o pticama utvrđena su Posebna područja zaštite čiji je zadatak štititi područja ključna za očuvanje ugroženih vrsta ptica i ptica selica. Naime, kada su uočeni nedostatci Direktive o pticama, koja predstavlja prvi europski akt zaštite prirode te prisutnost sve veće svijesti o ugroženosti biljnog i životinjskog svijeta starog kontinenta, godine 1992. donesena je najvažnija direktiva Europske unije koja se odnosi na zaštitu prirode, a to je Direktiva o staništima koja nadopunjuje Direktivu o pticama te u svom okviru imaju zadatak zaštititi više od tisuću biljnih i životinjskih vrsta i preko dvjesto europskih stanišnih tipova koja spadaju pod kategoriju ugroženih. Donošenjem Direktive o staništima utemeljena je ekološka mreža Natura 2000 kao novi model zaštite koji je pokazao veću učinkovitost. Tim sustavom zaštite utvrđena su područja na kojima se odgovarajućim mjerama upravljanja osigurava dugoročno povoljno stanje najugroženijih vrsta i staništa Europe $^{29}$. Znakovito je za ovu ekološku mrežu da nije propisan postotak teritorija pojedinih država koji bi trebao biti uključen u mrežu, nego ga se donosi na temelju postupka stručnog i znanstvenog vrednovanja koji je rezultat prostornog preklapanja svih područja koji se izdvajaju za svaku određenu vrstu i tip staništa. Što se tiče veličine proglašenih Natura 2000 područja one se mogu kretati od 1 ha pa do preko $5000 \mathrm{~km}^{2}$ sukladno tome o kojoj se vrsti ili stanišnom tipu kao cilju očuvanja radi, a prosječna veličina se kreće između 100 i 1.000 ha. Direktivom o pticama se u zemljama članicama EU proglašavaju područja koja su od posebnog značaja za ptičje vrste (Special Protection Areas - SPA), dok

\footnotetext{
${ }^{28}$ www.dzzp.hr

${ }^{29}$ GEO, 2012, 20-21.
} 
Direktivom o staništima se pokrivaju sve ostale europske vrste i tipovi staništa koje zemlje članice u svom zakonodavstvu određuju kao posebna područja očuvanja (SpecialAreasofConservation - SAC) koje prije proglašenja prolaze provjere i dobivaju odobrenje Europske komisije ${ }^{30}$. Za Naturu 2000 je potrebno naglasiti da bez obzira što se često poistovjećuje sa zaštićenim područjima u kojima bi ljudske djelatnosti bile u znatnoj mjeri ograničene ili pak zbog očuvanja bioraznolikosti isključene - u praksi tome nije tako. Kao cilj upravljanja ekološkom mrežom Natura 2000 postavlja se održivi razvoj koji u sebi nosi značajke održanja ili poboljšanja stanja očuvanosti ciljnih vrsta i stanišnih tipova određenog područja. Što se pak prijedloga većih razvojnih projekata tiče, ili možebitne promjene načina korištenja zemljišta u područjima Natura 2000, prolazi se postupak donošenja ocjene je li zahvat prihvatljiv za ekološku mrežu. Budući da se Natura 2000 temelji na održivom razvoju ako je ocjena u postupku pozitivna, zahvat se dopušta bez obzira što se nalazi u Natura 2000 području ${ }^{31}$. Iz svega toga proizlazi da cilj Nature 2000 nije zaustavljanje ukupne razvojne aktivnosti, nego postavljanje mjerila prema kojima se one mogu odvijati, a da se pritom očuva bioraznolikost. Sve navedeno upućuje na to da Natura 2000 u svojoj suštini otvara nove mogućnosti ruralnim područjima, posebice kroz ekoturizam, rekreaciju ili djelatnosti koje su usko vezane uz prirodu, kao npr. poljoprivreda i šumarstvo ${ }^{32}$. RH se uskladila s europskim zakonodavstvom u zaštiti prirode tako što je Vlada Republike Hrvatske proglasila ekološku mrežu koju čini sustav ekološki značajnih područja i koridora ${ }^{33}$. Ekološka mreža Republike Hrvatske obuhvaća $36,73 \%$ kopnenog teritorija i 15,42\% obalnog mora, a sastoji se od 781 Područja očuvanja značajnih za vrste i stanišne tipove (POVS) te 38 Područja očuvanja značajnih za ptice (POP) ${ }^{34}$.Ulaskom Republike Hrvatske u EU, Velebit je u cijelosti sa svim svojim prirodnim osobitostima postao dio ekološke mreže EU Natura 2000, što jasno očituje širi globalni značaj planine, kao najvećeg zaštićenog područja $\mathrm{RH}$.

\section{Pritisci i prijetnje}

Sve navedeno potvrđuje iznimno velik doprinos Velebita zaštiti prirode. $\mathrm{S}$ druge strane, zaštita prirode trebala bi doprinijeti opstanku i

\footnotetext{
${ }^{30}$ www.dzzp.hr

${ }^{31}$ Z. ŠIKIĆ, 2016, 35-36.

${ }^{32}$ www.dzzp.hr

${ }^{33}$ www.zastita-prirode.hr

${ }^{34}$ www.dzzp.hr
} 
održivom razvoju velebitske regije i lokalnog stanovništva tog područja, a to je u sadašnjoj situaciji postalo aktualno pitanje koje predstavlja svojevrsni izazov. Činjenica je da zaštita prirode uvijek nosi i određena ograničenja i striktno propisana postupanja i procedure. Namjena površina unutar ovakvih zaštićenih područja određena je prostornim planom posebnih obilježja, dok se upravljanje provodi temeljem deset-godišnjih planova upravljanja. I dok su planovi upravljanja izrađeni i za NP Paklenica i NP Sjeverni Velebit te i za PP Velebit, prostorni planovi su izrađeni samo za nacionalne parkove, dok za PP Velebit prostorni plan još uvijek nije izrađen niti donesen, a što predstavlja veliki problem u mogućem održivom razvoju ovoga područja. Nadalje, upravo zbog zaštite ovoga značajnog područja, propisana je i obvezna procjena utjecaja na prirodu, ekološku mrežu i na okoliš, što uvijek iziskuje dodatno i značajno vrijeme i financijska sredstva. S obzirom na to da je granica PP Velebit, 1981. godine određena na pomalo paušalan način, kao stvarna potreba nameće se njezina revizija kojoj bi prethodila stručna podloga. Na temelju takvog postupanja vrlo vjerojatno bi bilo moguće izuzimanje većih naseljenih cjelina kao što su Senj, Karlobag, Starigrad i Seline iz granice PP Velebit. Međutim, činjenica je i da postoji niz pritisaka na velebitsku prirodu. Velebit se nalazi u jednom od područja najveće erozije tla u Europi. Ovaj problem je osobito vidljiv u priobalnom dijelu. Izostanak ili slabije iskorištavanje (ispaša i košnja) travnjaka (smanjeno ljudsko djelovanje) uvjetuje njihovu sukcesiju u smjeru odgovarajućih tipova šikara i šuma, što dovodi do gubitka biološke raznolikosti. Postoje i pritisci šumarstva, i to u dijelu izgradnje šumskih putova i cesta, pritisci lova (krivolov, primjena netočnih podataka o brojnosti divljači), pritisci turizma, cestovnog prometa, sve veća eksploatacija vodnih resursa, pojava nelegalnog sakupljanja biljnih vrsta i leptira. Širenjem naselja, posebno u priobalnom dijelu, povećava se mogućnost onečišćenja (korištenje područja Parka za odlaganje otpada), značajnih promjena izvornog krajobraza te oštećenja i zatrpavanja speleoloških objekata. U odnosu na tzv. velike projekte, izgradnjom hidroenergetskih građevina na području Kosinja (akumulacijsko jezero i elektrana), što je sastavni dio projekta povećanja akumulacijskog prostora na rijeci Lici, postoji opasnost od promjena postojećeg podzemnog vodnog režima i na prostoru Parka, pa tako i cijelog podzemnog ekosustava. Jedan od potencijalnih izvora onečišćenja na ovome području su svakako još uvijek prisutne - uvažavanjem svega što je do sada poduzeto na ovome području - minski sumnjive površine, zagađene minama i neeksplodiranim ubojnim sredstvima, a posljedica su ratnih operacija tijekom Domovinskoga rata. 
U konačnici, gospodarenje ovim područjem mora se pažljivo planirati uz sustavno praćenja biološke raznolikosti kako bi se osigurao najbolji omjer između korištenja zemljišta i očuvanja prirode.

\section{Prilike}

U analizi situacije prethodno smo se na određeni način dotaknuli snaga i slabosti velebitskog područja te opisali moguće prijetnje. Sada ćemo navesti i mogućnosti ovoga područja kroz prilike koje vidimo isključivo održivim razvojem. Pažljivo analizirajući trendove unutar EU dolazi se do zaključka da je ono što se percipira kao moguća slabost zapravo velika prilika. Objašnjenje je u činjenici da troškovi održavanja mreže Natura 2000 u EU od 5,8 milijardi EUR-a godišnje, samo su djelić gospodarskih koristi koje mreža generira uslugama poput skladištenja ugljika, ublažavanja poplava, pročišćavanja vode, oprašivanja i zaštite riba, a čija je ukupna vrijednost 200-300 milijardi EUR-a godišnje. Obnavljanjem ekosustava i zelene infrastrukture mogu se poboljšati kvaliteta zraka i vode te obrana od poplava, smanjiti buka, potaknuti rekreacija i promicati prilike za zelena poduzeća. U okviru poljoprivredno-okolišnih praksi kojima se podupire biološka raznolikost, ekološki uzgoj je sektor s pozitivnim trendovima zapošljavanja koji privlači mlađu populaciju, osigurava $10-20 \%$ više radnih mjesta po površini zemljišta od konvencionalnog uzgoja te stvara dodanu vrijednost poljoprivrednih proizvoda. Održavanje zdravih morskih staništa i održivih ribljih stokova ključno je za dugoročni opstanak sektora ribarstva. Postoji važna gospodarska dimenzija borbe protiv invazivnih stranih vrsta koje sektorima EU uzrokuju štetu od najmanje 12 milijardi EUR-a godišnje ${ }^{35}$. Ako se zadržimo na našim nacionalnim relacijama, konkretnije, samo unutar velebitske regije, imamo i primjer dobre prakse, a on je na području i okruženju NP Paklenica. Poduzeto na tom području u najmanju je ruku zaustavilo opće negativne trendove koji su prisutni u drugim dijelovima velebitskog i podgorskog kraja. Broj posjetitelja tog parka odavno je prešao brojku od 100.000 posjetitelja, i to kroz znatno dužu, tj. šestomjesečnu sezonu. Planirani ukupni prihod tog parka za 2016. godinu iznosi $13.728 .198,00 \mathrm{kn}$, a ostvaruje ga 27 stalno zaposlenih i 6 zaposlenih na određeno vrijeme ${ }^{36}$. Međutim, što je značajnije, taj Park generira pozitivan gospodarski učinak tog područja.

\footnotetext{
${ }^{35} \mathrm{http}$ ://eur-lex.europa.eu
} 


\section{Zaključci}

Zaštićena područja pa tako i Velebit, sa svojim izuzetnim bogatstvom danas su predmet znanstvenih istraživanja, ekoloških edukacija te su u funkciji rekreacije i turizma. Tu svakako treba pridodati i značaj očuvanja kulturne baštine, ali i funkciju svojevrsnog doprinosa ekonomskoj vitalnosti lokalnih zajednica.

Bioraznolikost, kao temeljno obilježje velebitskog masiva, bogatstvo je ne samo naše domovine nego i značajka svjetske baštine, zato je potrebno i dalje planirati i provoditi inventarizaciju i praćenje njezina stanja.

Cilj Nature 2000 nije zaustavljanje ukupne razvojne aktivnosti, nego postavljanje mjerila prema kojima se one mogu odvijati, a da se pritom očuva bioraznolikost. Obnavljanjem ekosustava i zelene infrastrukture mogu se poboljšati kvaliteta zraka i vode te obrana od poplava, smanjiti buka, potaknuti rekreacija i promicati prilike za 'zelena poduzeća'.

Prostorni planovi posebnih obilježja su izrađeni samo za nacionalne parkove Paklenicu i Sjeverni Velebit, dok za PP Velebit prostorni plan još uvijek nije izrađen ni donesen, što predstavlja veliki problem u mogućem održivom razvoju ovoga područja.

Potrebno je pristupiti izradi stručne podloge za redefiniranje granice PP Velebit te moguće izuzimanje većih naseljenih cjelina kao što su Senj, Karlobag, Starigrad i Seline iz granice PP Velebit.

Perspektivu razvoja Podgorja treba promišljati integralno s cjelokupnim utjecajnim područjem, uključivo i morskim resursima.

Doprinos Velebita zaštiti prirode je izniman, pa se može zaključiti da zaštita tog ekosustava značajno doprinosi opstanku i održivom razvoju velebitske regije i posebno lokalne zajednice tog područja, te je zbog toga na ovom prostoru moguće povezati opće i globalne izazove današnjice s onim lokalnim.

\footnotetext{
${ }^{36} \mathrm{http}: /$ www.np-paklenica.hr
} 


\section{Internetski izvori}

http://velebit.meridian-arts.com (pristupljeno 21.10.2016.)

http://www.ppvelebit.hr/index.php/hr/prirodnabastina/bioloska-raznolikost/fauna (pristupljeno 21.10.2016.)

www.geo.com.hr (pristupljeno 21.10.2016.)

Ekološka mreža na području Velebita, DZZP, Zagreb, 2007.http://www.dzzp.hr/dokumenti upload/20100309/dzzp201003091232440.pdf (pristupljeno 07.08.2016.)

Izvješće Komisije Europskom parlamentu i Vijeću; Petogodišnji pregled provedbe strategije EU-a o biološkoj raznolikosti do 2020.

http://eur-lex.europa.eu/legalcontent/HR/TXT/?uri=CELEX\%3A52015DC0478 (pristupljeno 22.10.2016.)

http://www.np-paklenica.hr/index.php/multimedia/dokumenti (pristupljeno 22.10.2016.) http://ww.dzzp.hr/ekoloska-mreza/natura-2000/ekoloska-mreza-rh-natura-2000-1300. html (pristupljeno 07.08.2016.)

http://www.mint.hr/default.aspx?id=5396 (pristupljeno 21.10.2016.)

http://www.dzzp.hr/ekoloska-mreza/natura-2000/upravljanje-podrucjimanatura-2000-719.html (pristupljeno 07.08.2016.)

http://www.dzzp.hr/ekoloska-mreza/natura-2000/natura-2000-340.html (pristupljeno 07.08.2016.)

http://www.dzzp.hr/ekoloska-mreza/natura-2000/eu-direktive-718.html (pristupljeno 07.08.2016.)

http://www.zastita-prirode.hr/Ekoloska-mreza (pristupljeno 07.08.2016.)

\section{Literatura}

Jadran ANTOLOVIĆ - Maja PLESKALT - Zoran ŠIKIĆ, Zaštita prirode I dio, Zagreb, 2010, 41-43.

Jadran ANTOLOVIĆ - Maja PLESKALT - Zoran ŠIKIĆ, Zaštita prirode II dio, Zagreb, $2010,17$.

Državna uprava za zaštitu prirode i okoliša, Pregled stanja biološke i krajobrazne raznolikosti Hrvatske sa strategijom i akcijskim planovima zaštite, Zagreb, 1999, 16-20.

Sergej FORENBACHER, Velebit i njegov biljni svijet, Zagreb, 2001, 2-22.

GEO, 3/12, 2012, 20-21.

Denis GURLICA, Značaj planine Velebit u očuvanju prirode, Završni rad, Sveučilište u Zadru, Zadar, 2016.

Ivan MARTINIĆ, Upravljanje zaštićenim područjima prirode, Zagreb, 2010, 23-120.

Nacionalni park Paklenica, Plan upravljanja; Ministarstvo kulture Republike Hrvatske, Starigrad-Paklenica, 2007, 6-47.

Nacionalni park Sjeverni Velebit, Plan upravljanja; Ministarstvo kulture Republike Hrvatske, Krasno, 2007, 6-51. 
Ante PELIVAN, Velebit, Ekološki glasnik, Donja Lomnica, 2007, 21-63.

Jadranka ROTA, Danji leptiri NP Paklenica, Priroda, god. 89, br. 868, Zagreb, 1999, 26-27.

Zoran ŠIKIĆ - Tomislav ŠARIĆ - Slaven ZJALIĆ - Ivan ŽUPAN, Javna svijest o NATURA 2000 i gospodarenju otpadom u Hrvatskoj // Međunarodni znanstveno stručni skup Uloga komunikacija u gospodarenju otpadom, Zadar 19-21.3.2015./ Aleksandra Anić Vučinić, Sanja Kalambura (ur.), Zagreb: Geotehnički fakultet Sveučilišta u Zagrebu, 2015, 188-201.

Zoran ŠIKIĆ, Promišljanje održivog razvoja, priopćenje povodom 10. godišnjice Veleučilišta Marko Marulić, Odjel za ekologiju, agronomiju i akvakulturu Sveučilišta u Zadru, 2015.

Zoran ŠIKIĆ, Sustavi gospodarenja vodom, skripta, Sveučilište u Zadru, Zadar, 2016, 35-36.

Zakon o zaštiti prirode (NN 80/13)

\section{VELEBIT AND THE PROTECTION OF NATURE}

Summary

Velebit is a cult and mythical Croatian mountain, "a holy mountain", a symbol of national identity. Velebit is also the feather in the cap of Croatian protected areas of nature, a UNESCO biosphere reserve since 1978, a nature park since 1981, one part of it has been within the Paklenica National Park since 1949, and it has also been part of the Northern Velebit National Park since 1999. In its entirety, it is part of the EU Natura 2000 ecological network which clearly points to its global significance. In good weather, it can be seen entirely from the air at a height of 8,000 $\mathrm{m}$ and it has the shape of a dyke, which in a curve, bulges out into the sea. The littoral slope is higher and it rises from the sea to a height of $700 \mathrm{~m}$ to the lowest pass, then up to $1,757 \mathrm{~m}$ to the highest peak. From the northern landside the slope rises from $150 \mathrm{~m}$ to $1,150 \mathrm{~m}$ above the Lika plateau which lies at $500-600 \mathrm{~m}$ above sea level. Velebit is a centre of biodiversity and is the most significant endemic hub of flora and fauna in the Republic of Croatia. According to the last edition of the United Nations List of Protected Areas from 2003 there are 102,102 protected areas in the world with a total area of protection of $11.5 \%$ of the land and $0.5 \%$ of the surface of the sea. In the Republic of Croatia, according to the Protected Areas Register of the Ministry of Environment Protection and Nature as of $9^{\text {th }}$ September 2015, there are a total of 408 areas which encompass $8.56 \%$ of the total surface area of the Republic of Croatia, in other words $12.23 \%$ of the land territory and $1.94 \%$ of the territorial sea which is above the global average. The largest part of the protected area is in the category of nature parks which accounts for $4.56 \%$ of the total surface area of the Republic of Croatia, and the largest contribution to that is in fact Velebit. The current law about the protection of nature sets out nine categories of protected regions, which to a greater extent correspond to one of the internationally recognised categories of protected regions IUCN - the International Union for the Conservation of Nature. The wider region of Paklenica, with the surface area of 9,500 ha was, due to its natural foundations, geomorphological forms and preserved forests, declared amongst the first national parks, the same year as Plitvice Lakes. In the 
northern part of Velebit, with a surface area of 10,900 ha, the Northern Velebit National Park was declared in 1999, recognisable by its biodiversity and primaeval wilderness. In the vision of the Northern Velebit National Park this is distinguished as the fulcrum of the sustainable development of the local community based on tradition as well as a place of acquiring new knowledge. In addition to the two national parks the remaining part of Velebit, with an area of 200,000 ha, is protected as a nature park. All of this points to Velebit's exceptionally high contribution to the protection of nature. Whether in any way the protection of nature is a contribution to the survival and sustainable development of the Velebit region and in particular the local communities of this area is still a current issue, and likewise, whether it is possible in this area to link the general and global challenges of the present day with those of the local.

Keywords: Velebit, protected regions, biodiversity, sustainable development 